\title{
ANALYSIS OF THE RELATIONSHIP BETWEEN EXCHANGE RATE CHANGES AND PROFITABILITY IN TURKEY: EXAMPLE OF BIST MANUFACTURING SECTOR ${ }^{1}$
}

\author{
DOI: 10.17261/Pressacademia.2020.1312 \\ JBEF- V.9-ISS.4-2020(3)-p.304-319

\section{Emre Kurt ${ }^{1}$, Feyza Derekoy ${ }^{2}$} \\ ${ }^{1}$ Canakkale Onsekiz Mart University, PhD Student in Department of Business Management, Canakkale, Turkey. \\ emrekhurt@gmail.com, ORCID: 0000-0002-4170-8553. \\ 2istanbul Medipol University, Vocational School of Social Sciences, Istanbul, Turkey. \\ fderekoy@medipol.edu.tr, ORCID: 0000-0003-1508-7498.
}

Date Received: October 28, 2020

Date Accepted: December 11, 2020

To cite this document

Kurt, E., Derekoy, F. (2020). Analysis of the relationship between exchange rate changes and profitability in Turkey: example of BIST manufacturing sector. Journal of Business, Economics and Finance (JBEF), V.9(4), p.304-319.

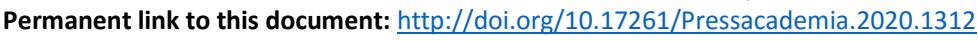

Copyright: Published by PressAcademia and limited licensed re-use rights only.

\begin{abstract}
Purpose- The aim of this study is to empirically investigate the relationship between the change in exchange rates and the profitability of firms in Turkey. The changes in real effective exchange rate as the change in exchange rates criteria and return on assets as well as return on equity are considered for measuring profitability.

Methodology- The sample of the research consists of 37 companies that are listed in BIST 100, operating in the manufacturing sector and whose data can be accessed completely. The data of the companies within the scope of the research were obtained from the official websites of Borsa Istanbul, Public Disclosure Platform, and Finnet and made ready for analysis. For the purpose of the research, panel data analysis, panel unit root tests, panel regression analysis, causality analysis, and moderating effect analysis were carried out.

Findings-. Changes in foreign exchange rates, foreign sales and asset size of the companies do not have any significant impacts on the return on assets and return on equity during the period between 1999-2019 in Turkey. It has also been found that asset size, foreign sales, and change in exchange rates are the reasons for the return on assets and similarly, asset size, foreign sales, and change in exchange rate are the reasons for the return on equity. Finally, changes in the foreign exchange rate and export sales have a short-term causal relationship with both return on assets and return on equity, and changes in the foreign exchange rate and total assets have a moderating effect on return on assets.

Conclusion- As a result of the research, it has been revealed that firms are affected by changes in foreign exchange rates with a delay. It means firms were likely be affected by the changes in exchange rates with a lag, and similarly, the changes in exchange rates affected financial performance with a lag. It has also been revealed from the research that firms effectively use internal and external hedging methods that help reduce the adverse impacts of the changes in foreign exchange rates.
\end{abstract}

Keywords: Exchange rates, changes in exchange rates, profitability, return on assets, return on equity. JEL Codes: F31, M49, L60.

\section{INTRODUCTION}

Due to the rising globalization in the world, trade potential has developed and the impact of the change in foreign exchange rates on economic performance has gained importance. Along with the de-escalated importance of the Bretton Woods system, many developed and developing countries have made adopted the free-floating exchange rate system and Turkey has also joined these countries as of 2001. Countries that have adopted the free-floating exchange rate system have begun to experience changes in the value of their national currencies. The appreciation or depreciation of the national currencies is expressed as a change in

${ }^{1}$ This manuscript is derived from the unpublished master's thesis titled as "Analysis of The Relationship between Currency Exchange Rate in Turkey and Financial Performance at BIST Manufacturing Sector" written by Emre Kurt under the supervision of Asst. Prof. Dr. Feyza Dereköy. 
foreign exchange rates. Even companies that do not operate internationally have been exposed to the impacts of foreign exchange rates due to the fluctuations in exchange rates and improved international trade. The change in exchange rates affects not only the economic activities of countries but also the overall profitability of companies.

This study aims to determine the level of association between the change in exchange rates and profitability ratios of the companies operating in Turkey. In this context; the foreign exchange rate, the change in exchange rates, profitability, and profitability ratios are firstly considered in the study. Then, the profitability ratios of 37 companies with accessible data operating in the manufacturing sector based on the Borsa Istanbul 100 index are calculated utilizing the financial statements and annual reports over the years 1999-2019. The association between the change in exchange rates and profitability ratios, which is the subject of the study, is examined using the panel data analysis method; the findings are evaluated and recommendations are made with reference to future studies.

\section{CONCEPTUAL FRAMEWORK}

In this part of the study, exchange rate, changes in the exchange rate, profitability and profitability ratios are explained.

\subsection{Exchange Rate and Exchange Rate Change}

As a result of the economic activities of a country, payments are made in the form of cash (banknote) and bank money (check, bill, money order), as well as in international payments, financing relationships are also made in both cash and bank money (Yıldız, 1988: 5).

Expressed as the name given to foreign currencies, foreign currency is defined as "all kinds of accounts, documents, and instruments that enable payment in foreign currency" pursuant to the Decree No. 32 on the Protection of the Value of Turkish Currency (Doğukanlı, 2001: 55). The exchange rate, however, is a price that differs from the price of any commodity. For instance, the change in the price of a good creates changes in the supply and demand for the good and the price of the substitute good, whereas the change in the exchange rate first leads to the global changes in the economy that affect the goods and services subject to international trade, and then other markets (Karluk, 2003: 371 - 372).

Unexpected fluctuations in the exchange rate, by causing changes of the foreign currency-dependent receivables, debt, income, and expenditure flows of companies dealing with foreign trade and monetary transactions in terms of the domestic currency, create changes in the market value of firms along with their net profitability. Unexpected foreign exchange rate fluctuations affect, not only the participants in the foreign market but also those who operate in the domestic market. Foreign currency price changes are intertwined with the production costs and sales prices of firms, as the reasons for overall price increases in the country. Furthermore, exchange rate fluctuations affect domestic firms by making domestic goods more expensive or cheaper than competing goods (Seyidoğlu, 2003: 246).

Exchange rate movements may also have an impact on financial performance and firm value since they affect the cash flows of internationally-operating firms (Madura, 2012: 311). Firms use several instruments and strategies to protect themselves against exchange rate impacts. These instruments and strategies are categorized under two groups such as internal and external (Doğanay, 2016: 152). Protection with in-house methods includes minimizing the exchange rate risk by utilizing the resources of the firm. Techniques such as selecting the currency type in the invoices, and determining the foreign currency inputs and outputs from the same currency type can be considered among the in-house methods. Firms tend to utilize some protection instruments to protect their asset-liability structures against the impacts of the exchange rate. These instruments, namely; forward and futures contracts, options, and swaps can be considered as external hedging methods (Karluk, 2009: 508-509).

\subsection{Profitability and Profitability Ratios}

Profit, which constitutes the first step toward the set of economic targets, is a type of attempt to the necessity of rational business decisions. Profit is the most crucial motive that stimulates company owners, managers, and other employees. Because, as long as the company makes more profit; the company owner would increase its capital, and the employees would increase their incomes (Akkuş, 2010: 24). Profit, which represents the most important success criterion for the company, is defined as the difference between sales revenue and cost (Müftüoğlu, 2010: 229).

Firms can boost their profitability by improving their efficiency or increasing their sales. However, the increase in profitability to be achieved with productivity increase is more effective than increasing sales. The ratios that are used to evaluate the profit can be separated into two such as profitability ratios according to sales and profitability ratios according to investment. The firm efficiency occurs upon evaluated along with these rates (Bolat, 2009: 10). 
Profitability ratios according to sales are divided into two as gross profit margin and net profit margin. The gross profit margin is calculated by dividing gross sales profit by net sales. Gross sales profit arises from the positive difference between net sales and cost of goods sold. After a firm's gross sales profit meets its operating expenses and other expenses, it is required to provide the shareholders with a sufficient amount of profit (Büker et al., 2014: 106). The net profit margin gives an idea of the net profitability of the firm's operations. The net profit margin is calculated by dividing the net profit for the period by the net sales amount (Düzakın, 2013: 88).

Profitability ratios according to investment are divided into two as the ratio of net profit to equity and the ratio of net profit to total assets. The associations between profit and capital are called "financial profitability". Since the purpose of the investment is to make a profit, it can be claimed that the relationship between the capital put into a company's business by its partners and profit is a crucial indicator in profitability analysis. Return on equity is calculated by dividing net profit, that is, profit after taxation, by equity. The ratio expresses the amount of profit per unit of the capital provided by the company's partners (Büker et al., 2014: 104). Return on assets indicates the extent to which the company becomes profitable concerning its total assets, and is calculated by dividing net profit by total assets. The higher the coefficient resulting from this calculation, the more successful the firm is considered in making profits. The ratio of net profit to total assets is also known as the rate of return on assets and refers to the gains from investment capital (https://businessht.bloomberght.com/piyasalar/haber/ 1583151-aktif-karlilik-nedir).

\section{LITERATURE REVIEW}

Adler and Dumas (1984) asserted that even companies without foreign currency assets and debts that neither engaged in foreign trade activities nor conducted trading transactions would have been exposed to foreign exchange risks. They subjected the exchange rate risk exposure to regression by associating it with the stock returns. They also claimed that the concept of regression coefficient openness was a unique and comprehensive measurement model that summarizes a firm's sensitivity in various aspects that could affect the change in exchange rates until sometime in the future.

Jorion (1990) tried to measure the relationship between the value of multinational companies operating in America and the foreign exchange rate. In the study, the data of 287 firms over the period 1971-1987 were analyzed using the OLS method with a two-model approach to measuring the foreign exchange risk exposure of the companies. In the first model, the impact of the change in exchange rates and market return on the stock returns of companies was investigated, and it was concluded that 15 out of 287 firms were statistically significantly and negatively affected. In the second model, the relationship between the foreign sales of companies and the change in exchange rates achieved in the first model was considered and it was concluded that the change in exchange rates positively affected the returns of the companies as well as the foreign sales of the companies.

Bartov and Bodnar (1994), upon considering the limited success of previous studies in documenting significant foreign exchange rate risks, investigated the extent to which firms were affected by exchange rate fluctuations by analyzing the relationship between US Dollar and equity value. The departure point in their studies had been the assumption that firms being affected by exchange rate fluctuations with a lag. The data used in their study covered the period between 1978-1989. In the first model they generated, they examined the impacts and lagged impacts within the same period. Upon examining the relationships within the same period, they could not draw a significant conclusion.

Therefore; upon considering the possibility of lagged impacts of the change in exchange rates, the researcher included the coefficients obtained from the first model as dependent variables in the second model. In the second model, it was also concluded that the change in exchange rates had lagged impacts on the firm's stock performance.

Bodnar and Wong (2003) generated a model by using income, profit, and expenditure percentages in terms of foreign currency to investigate US companies' exposure to exchange rate risks. In the generated model utilizing the data obtained over the period between 1977-1996; they concluded that firms that engaged in import and export activities had higher exchange rate risk elasticity, whereas smaller firms were more prone to exchange rate risks.

Doidge et al. (2006) investigated the sensitivity of 17,929 companies operating in 18 countries including Turkey to the change in exchange rates. They performed the panel data analysis utilizing the financial data of the companies selected for the study over the period between 1975-1999. According to the analysis results, it was detected that $8.2 \%$ of all companies and $4.5 \%$ of Turkish companies exhibited sensitivity to the change in exchange rates. It was concluded that the companies with no international sales exhibited lower sensitivity to the change in exchange rates.

Baggs et al. (2009) explicated the impacts of exchange rate volatility on the survival and sales of companies. Within the scope of the study, the data of the companies operating in Canada over the period between 1986-1997 were utilized. The researchers 
stated that the selection of the study period, during which the Canadian Dollar appreciated $30 \%$ in the first 6 years and depreciated $30 \%$ in the later 6 years, was not accidental. As a result of the research, they stated that the appreciated Canadian Dollar had an adverse relationship with the survival and sales of the firms. Nonetheless; they found that the change in exchange rates had less impact on the survival skills of more productive companies than others.

Fung and Liu (2009) examined the extent to which 188 firms that traded on the Taiwanese stock exchange were affected by the change in exchange rates using the data obtained over the period 1992-2000 via panel data analysis method. As a result of the study, it was being determined that the actual depreciation of the New Taiwan Dollar caused an increase in exports, domestic sales, and total sales values. Nevertheless; they stated that such real depreciation caused an increase in firm productivity.

Tomlin and Fung (2010) investigated the impact of real exchange rate movements on the productivity distribution of 128 manufacturing companies in Canada. Within the scope of the research study, they performed quantile regression analysis utilizing the data of the Canadian manufacturing sector (firm scale) over the period 1984-1997. As a result of the analysis; they found that quantile regression curves indicating the relationship between exchange rates and productivity followed a downward trend in some industries (feed, plastic bags, canvas products, wooden furniture, basic equipment, industrial fasteners, agricultural tools, signs and electronic markers). They concluded that the change in exchange rates had an impact on the firm productivity distribution, however; such a situation differs according to industry branches.

Dhasmana (2013) examined the impact of the real effective exchange rate on manufacturing firms in India. In the research study, the data of 250 manufacturing companies in the Bombay stock exchange 500 indexes over the period 2000-2012 were utilized. As a result of the research study; market power was emphasized as the most important determinant of financial performance in terms of exchange rate movements. Noting that there was an inverse relationship between currency appreciation and financial performance; the researcher suggested that large firms with sufficient financing opportunities might have reduced their sales volumes while preserving their profit margins.

Hanagaki and Hori (2015) investigated the extent to which the change in exchange rates affected the performance of Japanese firms and made evaluations using a large dataset of 360,000 Japanese firms over the period 1990-2003. The findings of the study claimed that Japanese firms, especially export-based firms, and the performances of medium-sized firms were positively affected by the depreciated Yen. However, such a positive effect was not found quite strong; they concluded that the relationship between Yen value and financial performance has not varied much throughout the last 20 years.

Kelilume (2016) explicated the extent to which the performances of the 20 most active firms in the Nigerian stock market were affected by the exchange rate volatility. Within the scope of the study, using Arrelano - Bond dynamic panel data and Arrelano Bover generalized moments method; return on assets, asset turnover ratio, and portfolio activity, as well as elasticity variables, were discussed. In the research study, it was concluded that the exchange rate volatility over the period 2004-2013 caused a negative impact on all three variables and adversely affected the performances of companies in Nigeria.

Williams (2018) investigated the impacts of the change in exchange rates on the financial performances of companies in Nigeria. In the study, the panel data were utilized over the period 2012-2016. As a result of the research, the existence of a positive relationship between the change in exchange rates and investment efficiency was detected.

Yücel and Kurt (2003) investigated the data of 152 firms whose stocks traded on the BIST over the period 2000-2002 utilizing models used by Adler and Dumas (1984), and Jorion (1990). Within the scope of the study, they selected the real effective exchange rate and the ISE 100 index as the control (market) variables. After performing their first analysis, they investigated the impacts of firms in terms of their exporting status on their sensitivity to exchange rates. They emphasized that, for a firm to become an exporter, the share of its foreign sales in total sales should have been higher than $20 \%$. According to the results of the research, they detected significant relationships in 11 of the firms that were under investigation in the Adler and Dumas model. 9 of those with significant relationships were among the exporting firms. According to the Jorion model, a significant relationship was found in 15 of the firms within the scope of the research, and it was emphasized that 14 out of those 15 firms were exporters. Based on the results they obtained from the two models, the researchers concluded that non-exporting firms were less affected by exchange rate movements rather than exporting firms.

Kızıl and Erdal (2012) investigated the extent to which the real exchange rate movements affected financial performance and whether or not they differed in each sector. Within the scope of the study, the data of 102 companies were utilized. They paid attention to the fact that the selected companies were in the manufacturing sector and had an average annual sales amount of approximately 83.5 trillion TL in the ISE. The study concluded that real exchange rates, which gained value, had positive impacts on foreign, domestic, and total sales and added values that were used to measure financial performance. 
Mutluay and Turaboğlu (2013) aimed at measuring the extent to which the exchange rate movements affected companies, based on the data obtained from 55 companies traded on the ISE. They analyzed the relationship between financial performance and exchange rate utilizing a regression model on the data of firms over the period 1997-2007. As a result of the research, they concluded that the changes in the exchange rate affected their financial performance with a lag and there was an opposite relationship between such level of influence and exports.

Akalın and Uzgören (2016) investigated the long-term relationship among firms' value-added, exchange rate, capital ratio, export volume, domestic sales, total sales, and profitability using econometric models. In the study, the Durbin - Hausman cointegration test and the Common Correlated Effect were used for the data obtained over the period 1993-2009. As a result of the study; the Durbin - Hausman test detected a long-term relationship among the variables. According to the Common Correlated Effect, they found that the increases in the exchange rate negatively affected the total sales and exports, and the added value created by the companies positively affected domestic sales, export amount, total sales, and profitability. They concluded that the increase in the capital/labor ratio also affected profitability positively.

Boyacıoğlu and Çürük (2016) investigated the extent to which the change in exchange rates affected stock returns. Within the scope of the study, they benefited from the data of 42 companies traded in the ISE 100 index and operated in the manufacturing and trade sectors over the period 2006-2014. Within the scope of the study, they conducted the panel data analysis to make predictions by calculating the changes in annual real exchange rates and stock returns. As a result of the study, they determined that changes in real exchange rates had positive impacts on the stock returns.

\section{DATA AND METHODOLOGY}

Studies in the literature reveal the existence of a relationship, which is less simultaneous than expected, between the change in exchange rates and firm profitability. There are three complementary explanations for such a weak relationship. The first involves the fact that investors tend to run late in learning about the exchange rate risks to which companies have been exposed. The second involves the fact that companies become insensitive to the change in exchange rates by successfully using financial derivatives and internal hedging methods to mitigate the adverse impacts of the change in exchange rates. The third involves the fact that data limitations and methodological weaknesses of empirical studies hamper the research studies' power (Dewenter et al., 2005: 120-122).

In this study, it was investigated whether a relationship existed between the change in exchange rates and firm profitability. In this context, the profitability ratios of 37 companies in the Borsa Istanbul (BIST) 100 index, operating in the manufacturing sector were calculated over the period between 1999 and 2019, and the relationship between the real exchange rate index changes and the profitability ratios was analyzed.

The scope of the research study consists of 42 companies that are listed on BIST 100 and operating in the manufacturing sector. However, the research is limited to 37 companies, whose whole dataset is accessed over the years 1999-2019. In order to draw more significant conclusions, the interval of the study period is determined as 1999-2019.

The manufacturing sector, which is a leading sector in many aspects within the economic system, is selected for the research study. Manufacturing companies play an important role in a modern economy and provide many crucial benefits for economic growth. The manufacturing sector increases productivity by contributing to import substitution and the expansion of exports, and provides foreign exchange earning capacity by encouraging the growth of investments at a faster pace than any other sector within the economy.

The annual change in real exchange rate index data obtained by means of the electronic data distribution system of the Central Bank of the Republic of Turkey is considered in the research for the change in the exchange rate. Moreover, the data regarding 37 companies trading in BIST 100 on total assets, total equity, net profit, current assets, fixed assets, and foreign sales are obtained from the financial statements published on websites such as www.borsaistanbul.com, www.kap.org.tr, and www.finnet.com.tr. Upon utilizing these data, the variables of "return on assets" and "return on equity", as the determinants in measuring the profitability of companies, are calculated.

In the study, the impacts of the change in foreign exchange rates (FOREX) (independent variable) on return on assets (ROA) and return on equity (ROE) (dependent variables) are analyzed via the panel data analysis method. Then, to examine whether or not the impact of the change in exchange rates on profitability is affected by foreign sales and asset size variables, asset size (ASSETS) and foreign sales (FORES) variables are determined as moderators. 
Total assets indicate the asset size of companies and are among the factors that affect profitability rates. Foreign sales represent the exporting potential of companies. Exporting companies are usually associated with high levels of productivity and profitability, and foreign sales are also factors that affect firm profitability. In the research study, the moderator effect of "asset size" and "foreign sales" variables on the relationship of "the change in exchange rates" with "return on assets" and "return on equity" is analyzed using regression analysis.

\section{FINDINGS}

The research study, which is conducted in the panel data position, examines the impact of the independent variables such as "change in exchange rates", "asset size" and "foreign sales" on the dependent variables such as "return on assets" and "return on equity". In the estimation of research models (panel data models), there are two approaches such as fixed effect and random effect. First of all, it is necessary to determine which of the fixed effect and random effect approaches would be appropriate for panel regression models. The following two models are tested within the scope of the research study:

$R O A_{i t}=C+\beta_{i t} A S S E T S+\beta_{i t} F O R E X+\beta_{i t} F O R E S+U_{\mathrm{I} t}$

$R O E_{i t}=C+\beta_{i t} A S S E T S+\beta_{i t} F O R E X+\beta_{i t} F O R E S+U_{\mathrm{i} t}$

After considering the fixed and random effect regression models in the selection of the appropriate model in the research study, the Hausman test was performed to make the decision. The hypotheses of the Hausman test statistic are established as follows:

$\mathrm{H}_{0}$ : The random effect is more appropriate.

$\mathrm{H}_{1}$ : The fixed effect is more appropriate.

Firstly, the fixed effect regression model is tested for Model 1 in the research study, and the obtained result sare presented in Table 1. Model 1 is tested first in the research. According to the Hausman Test, since the P-Value for the Cross-section random value is higher than 0.05 , the null hypothesis is accepted and it is determined that the appropriate model for panel regression regarding the model in Equation 1 is based on the random effect. The Hausman test results are presented in Table 3.1.

Table 1: Hausman Test Results for Equation 1

\begin{tabular}{|c|c|c|c|c|}
\hline & & Chi-square Statistic & Degree of Freedom & P-Value \\
\hline Hausman Test & & 0.000000 & 3 & 1.0000 \\
\hline \multicolumn{5}{|c|}{ Cross-Section Random Effect Test Comparisons } \\
\hline Variables & Constant & Random & Difference & P-Value \\
\hline FOREX & -0.000544 & -0.000540 & 0.000000 & 0.8899 \\
\hline ASSETS & -0.000000 & -0.000000 & 0.000000 & 0.9363 \\
\hline FORES & 0.000000 & 0.000000 & 0.000000 & 0.8051 \\
\hline
\end{tabular}

In the panel regression equation where the dependent variable is ROA, it was determined that the variables ASSETS, FOREX and FORES are not statistically significant and had no significant impact on the ROA variable. The obtained results are presented in Table 2.

Table 2: Random Effects Regression Results for Model 1

Method: Panel EGLS (Cross-Section Random Effects)
\begin{tabular}{|c|c|c|c|c|}
\hline Dependent Variable: ROA \\
\hline Variables & Coefficients & Standard Error & T statistic & P-Value \\
\hline C & 0.120259 & 0.025229 & 4.766765 & 0.0000 \\
\hline ASSETS & $-4.16 \mathrm{E}-13$ & $8.24 \mathrm{E}-13$ & -0.504295 & 0.6142 \\
\hline FOREX & -0.000540 & 0.000225 & -2.398978 & 0.0167 \\
\hline FORES & $6.03 \mathrm{E}-13$ & $1.70 \mathrm{E}-12$ & 0.354463 & 0.7231 \\
\hline
\end{tabular}

In the regression model where the dependent variable is ROE, the Hausman Test is performed to determine the estimation method. According to the Hausman Test, since the P-Value for the Cross-section random value is higher than 0.05 , the null hypothesis is accepted and it is determined that the appropriate model for panel regression regarding the model in Equation 2 is based on the random effect. The Hausman test results are presented in Table 3. 
Table 3: Hausman Test Results for Equation 2

\begin{tabular}{|c|c|c|c|c|}
\hline & & Chi-square Statistic & Degree of Freedom & P-Value \\
\hline Hausman Test & & 0.000000 & 3 & 1.0000 \\
\hline \multicolumn{5}{|c|}{ Cross-Section Random Effect Test Comparisons } \\
\hline \begin{tabular}{|l|} 
Variables \\
\end{tabular} & Constant & Random & Difference & P-Value \\
\hline ASSETS & -0.000000 & -0.000000 & 0.000000 & 0.8190 \\
\hline FOREX & -0.002588 & -0.002424 & 0.000000 & 0.4599 \\
\hline FORES & 0.000000 & 0.000000 & 0.000000 & 0.6305 \\
\hline
\end{tabular}

It is determined that the variables ASSETS, FOREX and FORES are not statistically significant and have no significant impact on the ROE variable for the panel regression equation in which the dependent variable is ROE. The obtained results are presented in Table 4.

Table 4: Regression Results for Model 2 According to Random Effect

Method: Panel EGLS (Cross-Section Random Effects) Dependent Variable: ROE

\begin{tabular}{|c|c|c|c|c|}
\hline Variables & Coefficients & Standard & T-statistic & P-Value \\
\hline C & 0.349106 & 0.114896 & 3.038444 & 0.0025 \\
\hline ASSETS & $-4.13 \mathrm{E}-13$ & $3.61 \mathrm{E}-12$ & -0.114349 & 0.9090 \\
\hline FOREX & -0.002424 & 0.001069 & -2.267617 & 0.00236 \\
\hline FORES & $8.91 \mathrm{E}-12$ & $7.49 \mathrm{E}-12$ & 1.189864 & 0.2345 \\
\hline
\end{tabular}

\subsection{Unit Root Test}

In econometric time-series, for the econometric model to yield significant results, the stationarity of the time-series must first be tested. In the case of stationarity, there should be no symmetrical change in the variance and mean of the series and the covariances of all observation values of the series should be equal to a constant value (Göktaş et al., 2019: 159). If the variance and mean of the series are independent of time and the covariance is based on intertemporal differences, the series is said to be stationary. Stationary series are series that do not contain unit roots (Sarıkovanlık et al., 2019: 185). In the model estimated with non-stationary time-series, parameter values and statistics are calculated incorrectly, and in this case, econometrically inconsistent results are obtained (Göktaş et al., 2019: 159). The hypotheses established for the research variables are as follows:

$\mathrm{H}_{0}$ : The series does not contain any unit roots. The series is not stationary $\left(\rho_{i}=\rho=1\right)$

$\mathrm{H}_{1}$ : The series does not contain any unit roots. The series is stationary $\left(\rho_{i}=\rho<1\right)$.

In determining whether the panel data is stationary over time, both the panel data applied to the balanced panel and the panel unit root tests used for the series that are not sought to be a balanced panel are taken into consideration together. Panel unit root tests are performed separately for each variable. Among the panel unit root tests, the main reference is the results of the Levin, Lin and Chu t-test (Sarıkovanlık et al., 2019: 193). According to the unit root tests, it is determined that ROA and ROE dependent variables are stationary at the level, whereas ASSETS, FOREX, and FORES variables are not stationary at the level, and upon taking the second differences of the series, they are determined as stationary. Since the series are stationary, they do not contain any unit roots and no long-term relationship is determined. The obtained results are presented in Table.5.

Table 5: Panel Units Root Tests

\begin{tabular}{|l|c|c|c|c|c|c|c|c|c|c|}
\hline & \multicolumn{2}{|c|}{ ROA (0) } & \multicolumn{2}{c|}{ ROE (0) } & \multicolumn{2}{c|}{ ASSETS (2) } & \multicolumn{2}{c|}{ FOREX (2) } & \multicolumn{2}{c|}{ FORES (2) } \\
\hline Methods & Statistic & P-Value & Statistic & P-Value & Statistic & P-Value & Statistic & P-Value & Statistic & P-Value \\
\hline $\begin{array}{l}\text { Levin, Lin } \\
\text { and Chu t }\end{array}$ & -7.3576 & 0.0000 & -7.8042 & 0.0000 & -12.2558 & 0.0000 & -8.99255 & 0.0000 & -9.63503 & 0.0000 \\
\hline $\begin{array}{l}\text { PP - Fisher } \\
\text { Chi-square }\end{array}$ & 304.955 & 0.0000 & 310.008 & 0.0000 & 2261.39 & 0.0000 & 9745.96 & 0.0000 & 1350.07 & 0.0000 \\
\hline
\end{tabular}




\subsection{Panel Cointegration Test}

In the time-series regarding the panel data, the approach that was developed to examine the long-term relationship is called the cointegration approach in panel data analysis as in time-series (Guriş, 2015: 269). In cases where the economic time-series contain unit roots, the linear combinations of these series can be stationary, and the series can be related in the long-run (Tatoğlu, 2012: 233). Cointegration tests are performed to test this relationship. The prerequisite of the panel cointegration test requires that the variables should not be stationary in level values and the first difference of all variables should be stationary (Sarıkovanlık et al., 2019: 196). Since the ROA and ROE variables are determined to be stationary at the level, whereas the variables ASSETS, FOREX, and FORES are determined to be stationary at the second differences according to the Levin, Lin and Chu t-test, it is decided to perform causality analysis without the necessity of performing cointegration test.

\subsection{Panel Causality Test}

In time-series analysis, causal relationships between variables are tested with causality analysis. In the causality analysis, the direction of the relationship between two variables is investigated by the Granger causality-based causality analyses. As in timeseries, the investigation of causal relationships in panel data models is based on the Granger causality logic. In the Granger causality analysis, if the value of a current $Y$ variable is predicted better than the current value of the other variable $X$ than the past values; it can be mentioned that there is a causal relationship running from variable $X$ to variable $Y$ (Güriş, 2015: 295).

It is possible to mention four different tests, namely Panel VECM (2008), Coining and Pedroni (2008), Emirmahmutoğlu, and Köse (2011), and Dumitrescu and Hurlin (2012), which influence the panel causality literature. In accordance with the aim of the study, the method developed by Dumitrescu and Hurlin (2012) is used to test the presence of a causal relationship among the series. This method is used advantageously by taking both cross-sectional dependence and heterogeneity among the countries that constitute the panel into account, regardless of the comparison between time dimension $(T)$ and the cross-section dimension $(N)$, and it can produce efficient results in unbalanced panel datasets (Dumitrescu and Hurlin, 2012). Another feature of the Dumitrescu and Hurlin test involves the fact that it can analyze both in the presence of a cointegrated relationship and in the absence of such a relationship. Therefore, the Dumitrescu-Hurlin panel causality test is performed for causality analysis utilizing this dataset in which there is no cointegrated relationship.

In the Dumitrescu-Hurlin panel causality test, when $\mathrm{X}$ and $\mathrm{Y}$ represent two stationary processes observed during $T$ period for $N$ units, for each unit (i) at time $t$, it considers the linear heterogeneous model in Equation 3;

$$
y_{i t}=\alpha_{i}+\sum_{k=1}^{k} \gamma^{(k)} y_{i t-k}+\sum_{k=1}^{k} \beta^{(k)} x_{i t-k}+\varepsilon_{i t}
$$

In Equation 3, the firm-specific impacts of $\alpha \mathrm{i}, \gamma^{(k)}$ and $\beta^{(k)}$ are assumed to be the same for all firms. Since the study aims to determine the possible impacts of changes in exchange rates, asset size, and foreign sales of 37 firms on the company's return on assets and return on equity, the study has two dependent variables. These variables are the return on assets and return on equity of the firms. Other variables are independent variables, and unilateral causality running from causal variables to consequential variables are examined.

The VEC Granger Causality / Dumitrescu Hurlin Test is used as the method in the study. When the return on assets (ROA) is the dependent variable, it is determined that variables that are causal with one lag are causes of return on assets.

Accordingly, the following would be stated regarding the activities of 37 companies:

- $\quad$ Firm size is a short-term cause of the return on assets in the Granger-Dumitrescu Hurlin sense (Prob. $=0.0000$ ).

- Changes in exchange rates for firms is a short-term cause of the return on assets in the Granger-Dumitrescu Hurlin sense (Prob. $=0.0006)$.

- $\quad$ Foreign sales of firms are a short-term cause of the return on assets in the Granger-Dumitrescu Hurlin sense (Prob. = 0.0008). The obtained results are presented in Table 6. 
Table 6: Panel Causality Test Results Regarding Return on Assets

\begin{tabular}{|c|c|c|c|}
\hline \multicolumn{4}{|c|}{ Method: Pairwise Dumitrescu Hurlin Panel Causality Tests } \\
\hline \multicolumn{4}{|c|}{ Dependent Variable: (ROA) } \\
\hline \begin{tabular}{|l|} 
Variables \\
\end{tabular} & Coefficient of Concordance & Normal Distribution & P-Value \\
\hline ASSETS & 2.44920 & 4.50146 & 7.E-06 \\
\hline FOREX & 2.14010 & 3.44405 & 0.0006 \\
\hline FORES & 2.11848 & 3.37007 & 0.0008 \\
\hline
\end{tabular}

The Dumitrescu Hurlin Panel causality test is conducted to investigate whether or not the independent variables have a possible causal relationship with equity. According to the Dumitrescu Hurlin Panel causality test:

- $\quad$ Asset sizes of firms Granger-Dumitrescu Hurlin cause return on equity in the short-run (Prob. $=0.0000$ ).

- The change in exchange rates for firms Granger-Dumitrescu Hurlin causes the return on equity in the short-run (Prob. = 0.0001).

- Foreign sales of firms are short-term causes of the return on equity in the Granger-Dumitrescu Hurlin sense (Prob. = 0.0000). The obtained results are presented in Table.7.

Table 7: Panel Causality Testi Results Regarding Return on Equity

\begin{tabular}{|c|c|c|c|}
\hline \multicolumn{4}{|c|}{ Method: Pairwise Dumitrescu Hurlin Panel Causality Tests } \\
\hline \multicolumn{3}{|c|}{ Dependent Variable: (ROE) } & \multirow[b]{2}{*}{ P-Value } \\
\hline Variables & Coefficient of Concordance & Normal Distribution & \\
\hline ASSETS & 3.09457 & 6.70919 & 2.E-11 \\
\hline FOREX & 2.26318 & 3.86510 & 0.0001 \\
\hline FORES & 2.44750 & 4.49563 & 7.E-06 \\
\hline
\end{tabular}

\subsection{Moderating Effect}

In the study, it is also investigated whether or not a moderating effect of asset size and foreign sales exists between the change in exchange rates and the profitability variables, which are the dependent variables of the research. Since the moderating effect analysis is based on regression analysis, firstly the extreme values in the dataset are investigated by multivariate outlier analysis. The feature of multivariate outlier analysis is that all variables used in the research can be taken into account together. In multivariate outlier analysis, the variables are not single but based on a multivariate approach with the Mahalanobis Distances. High values in the Mahalanobis Distances can be extreme values and values with probability $\mathrm{P}<0.01$ in the study are accepted as multivariate outliers and are excluded from the dataset. The existence of the moderating effect is realized with the help of the Process Macro application developed by A. F. HAYES in IBM SPSS 25.0 software.

The moderator effect examines whether or not the impact of an influencing variable $X$ on the affected variable $Y$ is affected depending on a variable such as $\mathrm{W}$. In the moderator effect, it is examined that the impact of $\mathrm{X}$ on $\mathrm{Y}$ is determined and moderated by $\mathrm{W}$ variable. In other words, $\mathrm{X}$ is the moderating variable that indicates in which situations the impact of the variable on the $\mathrm{Y}$ variable would increase or decrease or on what such impact depends (Gürbüz, 2019: 81-88). The research model in which foreign sales and asset size are moderator variables and return on assets is the dependent variable is illustrated in Figure 1.

Figure 1: Moderating Model Regarding the Return on Assets

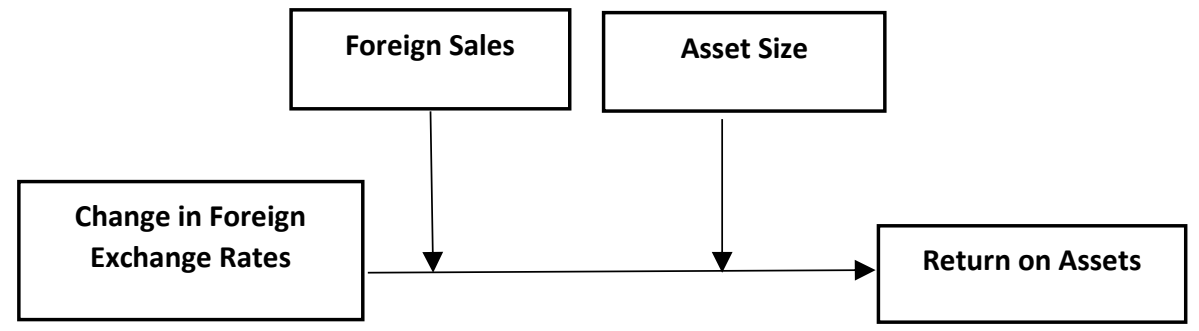


The research model in which foreign sales and asset size are moderator variables and return on equity is the dependent variable is presented in Figure 2.

Figure 2: Moderating Model Regarding the Return on Equity

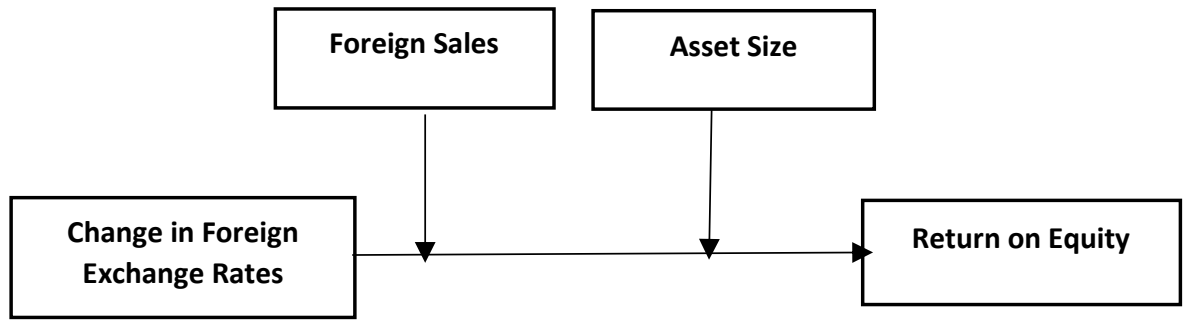

The independent variables included in the moderating regression analysis explain $6.8 \%$ of the change in the return on assets $(F=$ $7.575, P=0.000$ ). As a result of the regression analysis, the significance of $\beta i$ of the independent variable is examined and the change in the exchange rate and foreign sales are found to be significant. The asset size coefficient is not found to be statistically significant. The moderating effects for the model are examined, and the interactional effect of the change in exchange rates and the foreign sales variables are not found statistically significant $(t=-1.175, P=0.241)$. The interactional effect of the change in exchange rates and the asset size variables are found to be statistically significant $(t=2.378, P=0.018)$. Also, if the confidence interval ( $\mathrm{LLCl}-\mathrm{ULCl}$ ) includes a value of zero, the regression coefficient is not found to be statistically significant. The obtained results are presented in Table 8.

Table 8: Summary and Coefficients Regarding Moderator Role of Foreign Sales and Asset Size

\begin{tabular}{|c|c|c|c|c|c|c|}
\hline & $\boldsymbol{\beta}_{\mathbf{i}}$ & Standard Error & $\mathbf{t}$ & $\mathbf{p}$ & $\mathbf{L L C l}$ & ULCI \\
\hline Constant & 0.015 & 0.043 & 0.343 & 0.732 & -0.069 & 0.099 \\
\hline FOREX & -0.176 & 0.043 & -4.075 & 0.000 & -0.260 & -0.091 \\
\hline FORES & -0.142 & 0.068 & -2.093 & 0.037 & -0.275 & -0.009 \\
\hline Int_1 & -0.079 & 0.067 & -1.175 & 0.241 & -0.210 & 0.053 \\
\hline ASSETS & -0.033 & 0.068 & -0.482 & 0.630 & -0.167 & 0.101 \\
\hline Int_2 & 0.160 & 0.067 & 2.378 & 0.018 & 0.028 & 0.293 \\
\hline \multicolumn{2}{|l|}{} & $\begin{array}{l}\text { Int_1 } \\
\text { Interactional Effect }\end{array}$ & $\begin{array}{l}\text { FOREX } \times \text { FORES } \\
\text { Int_2 }\end{array}$
\end{tabular}

$R=0.261, R^{2}=0.068, F=7.757, P=0.000$

For Int_1 $\wedge R^{2}=0.025, F=1.3797, P=0.2407$

For Int_2 $\wedge R^{2}=0.0102, F=5.6549, P=0.0178$

In the study, without determining the moderating effect for the foreign sales variable, the foreign sales variable in Figure 1 is excluded from the model, and the analysis is repeated.

The independent variables included in the repeated analysis explain $5.9 \%$ of the changes in the return on assets variable $(F=$ $10.827, P=0.000$ ). Parameter values for all independent variables in the regression equation are found to be statistically significant. The change in the exchange rates decreases the return on assets significantly $(t=-4.064, P=0.000)$. Similarly, the increase in asset size variable significantly decreases the return on assets $(t=-3.074, P=0.002)$. It is examined whether or not the asset size variable has a moderating effect and the value of $\beta=0.104$ for the interactional effect (Int_1) variable is found to be significant $(\mathrm{t}=2.457, \mathrm{P}=0.014)$. Also, the confidence interval $(\mathrm{LLCl}-\mathrm{ULCl}$ ) does not include the value zero as in the independent variables. Moreover, upon including the asset size variable in the analysis, the existence of a change of 0.0109 units in the $\wedge R^{2}$ 
value is determined, and the value of $\mathrm{R}^{2}$ increases $(F=6.0363, \mathrm{P}=0.0143)$. Therefore, the asset size variable has a moderator effect. The obtained results are presented in Table 9.

Table 9: Summary and Coefficients Regarding Moderator Role of Asset Size

\begin{tabular}{|c|c|c|c|c|c|c|}
\hline & $\boldsymbol{\beta}_{\mathbf{i}}$ & Standard Error & $\mathbf{t}$ & $\mathbf{p}$ & $\mathbf{L L C l}$ & ULCI \\
\hline Constant & 0.015 & 0.043 & 0.354 & 0.724 & -0.069 & 0.100 \\
\hline FOREX & -0.176 & 0.043 & -4.064 & 0.000 & -0.260 & -0.091 \\
\hline ASSETS & -0.138 & 0.045 & -3.074 & 0.002 & -0.226 & -0.050 \\
\hline Int_1 & 0.104 & 0.043 & 2.457 & 0.014 & 0.021 & 0.188 \\
\hline \multicolumn{2}{|l|}{ Interactional Effect } & Int_1 & \multicolumn{2}{l|}{ FOREX $\times$ ASSETS } \\
\hline
\end{tabular}

$R=0.243, R^{2}=0.059, F=10.82, P=0.000$

$\Lambda R^{2}=0.0109, \mathrm{~F}=6.0363, \mathrm{P}=0.0143$

After determining the impacts of the moderator variable, the situational effects of the moderator variable should be examined. Three different regression statistics are obtained regarding whether or not the effects of change in exchange rates on return on assets are significant when the moderator variable asset size is low (-0.769), medium (-0.384), and high (0.964). Regression values obtained according to three different conditions are presented in Table 10.

Table 10: Situational Effect of Asset Size as the Moderator Variable

\begin{tabular}{|c|c|c|c|c|c|c|}
\hline ASSETS & Effect & Standard Error & $\mathbf{t}$ & $\mathbf{P}$ & LLCl & ULCI \\
\hline-0.769 & -0.256 & 0.056 & -4.535 & 0.000 & -0.367 & -0.145 \\
\hline-0.384 & -0.216 & 0.048 & -4.539 & 0.000 & -0.309 & -0.122 \\
\hline 0.964 & -0.075 & 0.057 & -1.317 & 0.188 & -0.187 & 0.037 \\
\hline
\end{tabular}

According to Table 10, if the asset size assumes low and medium values, the impact of the changes in foreign exchange on the return on assets is significant, whereas there is no significant relationship when the asset size is high $(t=-1.317, P=0.188)$. Moreover, if the asset size is high, the confidence interval includes zero value $[-0.187 ; 0.037]$.

Therefore, asset size does not have a moderating effect upon assuming high values. When asset size as the moderator variable assumes a low value, its impact on the dependent variable is significant and determined as $-0.256(t=-4.535, P=0.000)$. Similarly, if it assumes a medium value, its significant impact on the dependent variable becomes $-0.216(t=-4.535, P=0.000)$. In order to perceive the moderating effects better, one should examine the moderating effect chart illustrated in Figure. 3 utilizing the Slope test analysis method developed by Aiken et al. (1991). Since there is no slope in the slope analysis illustrated in the figure for the high-level moderating effect of the asset size variable, it cannot be said to have a significant moderating effect. Graphical illustration of the moderator variable effects is shown in Figure 3. 
Figure 3: Graphical Illustration of Moderator Variable Effects

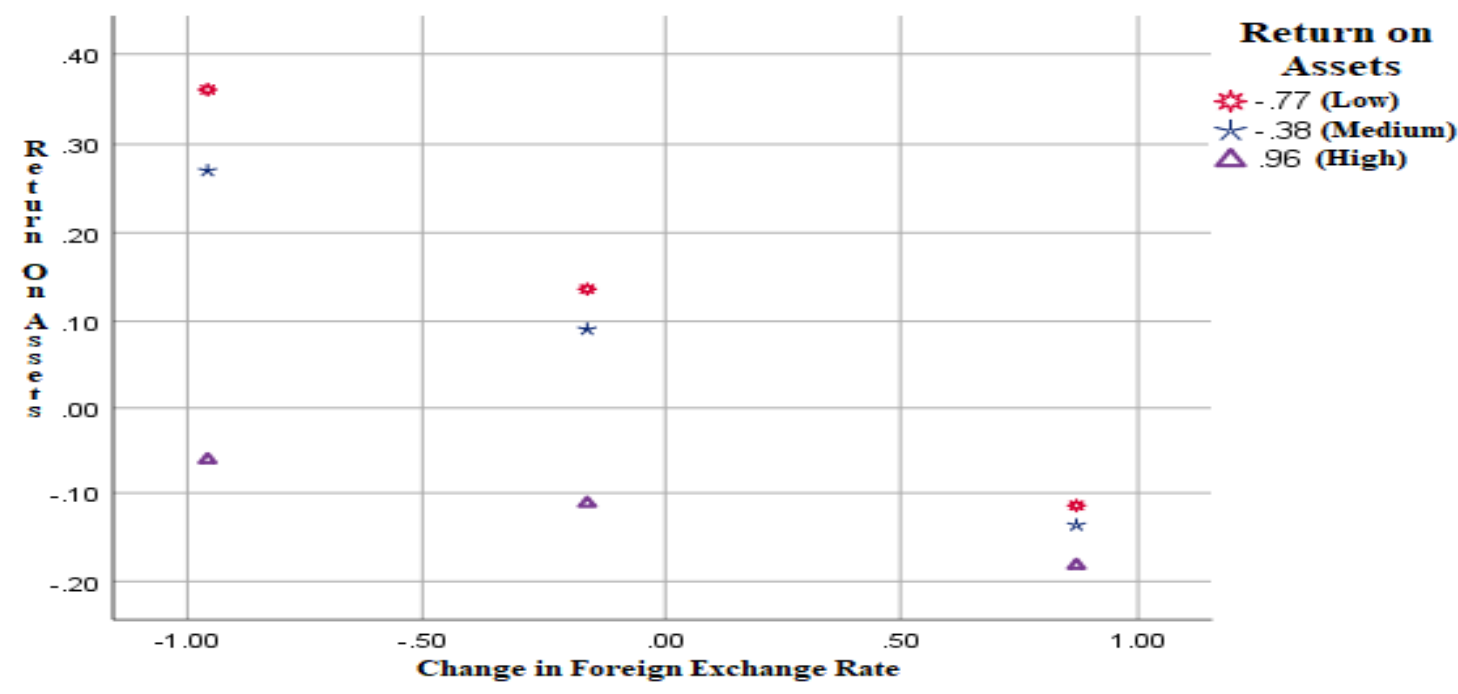

According to Figure 3, the opposite relationship between return on assets and exchange rate strengthens it, even more, when the moderator variable asset size assumes high or medium values. Therefore, the change in exchange rates increases, and asset size values decrease, while the return on assets decreases. When the moderator variable asset size assumes high values, it has no impact on the relationship between the change in exchange rates and returns on assets. When the asset size variable assumes low values, the change in exchange rates ranges between 0.3695 and -0.1110 . When it assumes medium values, the change in exchange rates ranges between 0.2773 and -0.1276 . The moderator effects of asset size according to its different values are presented in Table 11.

Table 11: Moderator Effects According to Different Values of Asset Size

\begin{tabular}{|c|c|c|}
\hline FOREX & ASSETS & ROA \\
\hline-0.9702 (Low) & -0.7689 (Low) & 0.3695 \\
\hline-0.1172 (Medium) & -0.7689 (Low) & 0.1512 \\
\hline 0.9076 (High) & -0.7689 (Low) & -0.1110 \\
\hline-0.9702 (Low) & -0.3836 (Medium) & 0.2773 \\
\hline-0.1172 (Medium) & -0.3836 (Medium) & 0.0934 \\
\hline 0.9076 (High) & -0.3836 (Medium) & -0.1276 \\
\hline-0.9702 (Low) & 0.9640 (High) & -0.0450 \\
\hline-0.1172 (Medium) & 0.9640 (High) & -0.1089 \\
\hline 0.9076 (High) & 0.9640 (High) & -0.1857 \\
\hline
\end{tabular}

The research model is illustrated in Figure 2. where foreign sales and asset size are moderating, and return on equity is the dependent variable, is carried out using Process Macro. Summary and coefficients regarding the moderator role of foreign sales and asset size are presented in Table 12. 
Table 12: Summary and Coefficients Regarding Moderator Role of Foreign Sales and Asset Size

\begin{tabular}{|c|c|c|c|c|c|c|}
\hline & $\beta_{i}$ & Standard Error & $\mathbf{t}$ & $\mathbf{p}$ & LLCl & $\mathrm{ULCl}$ \\
\hline Constant & 0.011 & 0.043 & 0.248 & 0.804 & 0.074 & 0.096 \\
\hline FOREX & -0.198 & 0.043 & -4.547 & 0.000 & -0.283 & -0.112 \\
\hline ASSETS & -0.016 & 0.069 & -0.226 & 0.821 & -0.151 & 0.120 \\
\hline Interaction 1 & 0.094 & 0.068 & 1.386 & 0.166 & -0.039 & 0.228 \\
\hline FORES & -0.088 & 0.068 & -1.284 & 0.200 & -0.222 & 0.047 \\
\hline Interaction 2 & -0.027 & 0.068 & -0.404 & 0.686 & -0.160 & 0.106 \\
\hline \multicolumn{2}{|c|}{ Interactional Effect } & $\begin{array}{l}\text { Int_1 } \\
\text { Int_2 }\end{array}$ & \multicolumn{4}{|c|}{$\begin{array}{l}\text { FOREX } \times \text { ASSETS } \\
\text { FOREX } \times \text { FORES }\end{array}$} \\
\hline
\end{tabular}

$R=0.225, R^{2}=0.051, F=5.511, P=0.000$

$\Lambda R^{2}=0.0035, F=1.9211, P=0.1663$

The affecting variables included in the moderating regression analysis explain $5.1 \%$ of the change on the return on equity $(F=$ $5.511, P=0.000)$. As a result of the regression analysis, the significance of $\beta_{i}$ of the independent variables is examined and the parameter of the change in the exchange rates $(\beta=-0.198)$ is found to be statistically significant $(t=-4.547, P=0.000)$. Foreign sales $(\beta=-0.088)$ and asset size $(\beta=-0.016)$ parameters are not found significant. The moderating effects for the model are examined and the change in the exchange rate and the parameter value for the interactional effect of the asset size $(\beta=0.094)$ variable are not found to be statistically significant $(t=1.386 . P=0.166)$. Similarly, the parameter value for the interactional effect of the change in exchange rate and foreign sales $(\beta=-0.027)$ variables is found to be statistically insignificant $(t=-0.404$. $P=0.686)$. A similar situation is observed in the confidence interval. The confidence interval of all variables. except for the change in exchange rates, includes the zero value. Therefore, no moderator effect is detected in the model illustrated in Figure 2 . Furthermore, upon including the variables of asset size and foreign sales in the analysis, it is determined that there is a change of 0.0035 units in the $R^{2}$ value, and that it does not significantly increase the $R^{2}$ value $(F=1.9211, P=0.1663)$.

\section{DISCUSSIONS AND CONCLUSION}

Changes in the exchange rates may affect the profitability of firms by providing economic dynamism in the presence of matters such as the cost of imported inputs, the price of export products or the cost of foreign borrowing. The relationship between the change in exchange rates and profitability has a crucial impact on economic growth. Exporting companies are more prone to be affected by the changes in exchange rates. These firms pay more attention to profitability ratios since they are often associated with high levels of productivity and profitability.

The aim of this study is to empirically investigate the relationship between the change in exchange rates and the profitability of firms in Turkey. The changes in real effective exchange rate as the change in exchange rates criteria and return on assets as well as return on equity are considered for measuring profitability. In the research study, the variables of changes in exchange rate, asset size and foreign sales are in the position of reasons, whereas the return on assets and return on equity are the results. The data of 37 firms within the scope of the research study over the period 1999-2019 are analyzed using the panel data and regression analysis methods. In the study, two distinct models are tested using the panel data analysis method. In the first model, the impact of changes in exchange rates, asset size, and foreign sales variables on profitability are analyzed; whereas the impacts of the change in exchange rates, asset size, and foreign sales variables on return on equity are examined in the second model.

Two hypotheses such as "random effect is more appropriate" and "fixed effect is more appropriate" are established in selecting which of the estimation method the panel data models would be suitable. In the study, firstly, the fixed effect regression model for the first model is subjected to the Hausman test and the hypothesis claiming that "the random effect is more appropriate" is accepted since the P-Value becomes higher greater than 0.05 according to the Cross-Section Random test. In the panel regression equation where the dependent variable is return on assets, it is determined that asset size, change in exchange rates, and foreign sales variables do not have a significant impact on return on assets. 
The second model, in which return on equity is selected as the dependent variable, employs the Hausman test and the hypothesis claiming that "Random effect is appropriate since the P-Value is higher than 0.05." is accepted. The second model, in which return on equity is selected as the dependent variable, is subjected to panel regression analysis and it is determined that the variables of asset size, the change in exchange rates and foreign sales do not have a significant impact on return on equity.

Following the panel regression analysis in the study, unit root tests are conducted to determine whether or not the variables within the scope of the study are stationary. According to panel unit root test results, it is determined that return on assets and return on equity are stationary; the variables of asset size, the change in exchange rates and foreign sales are not stationary, and the series become stationary upon taking the second differences. As a result; since the application condition of the cointegration test performed to examine the long-term relationship in time-series is not fulfilled, the causal relationship is examined without conducting the cointegration test.

The VEC Granger Causality / Dumitrescu-Hurlin test is used as a means for causality analysis. Since the return on assets is the dependent variable, it is determined that the independent variables such as asset size, foreign sales, and change in exchange rates are the reasons for the return on assets. The asset size of the companies, the change in exchange rate for the companies, and the foreign sales of the companies emerge as the short-term causes of the return on assets in the Granger-Dumitrescu Hurlin sense. According to the causality test result regarding the other dependent variable; it is determined that the variables such as asset size, foreign sales, and change in exchange rate are the reasons for the return on equity. The asset size of the companies, the change in exchange rates for the companies, and the foreign sales of the companies emerge as the short-term causes of the return on equity in the Granger-Dumitrescu Hurlin sense.

In the last part of the study, the moderating effect between asset size / foreign sales variables and the change in exchange rate / return on assets / return on equity is examined by regression analysis. According to the analysis results, it is determined that the change in exchange rates and the asset size variables have a moderating effect on the return on assets. In this case, return on assets decreases along with the increase in asset size variable, and similarly, return on assets decreases along with the change in exchange rates. Upon examining the situational effect of asset size, which is a moderator variable, on the change in exchange rates; it is determined that there is no significant relationship in the case of asset size with high values, although the asset size with low and medium values, the impact of the change in exchange rate on return on assets is significant. This means that if the asset size gets high values, there is no moderator effect. Also, it is determined that foreign sales and changes in exchange rates do not have a moderating effect on return on assets. Likewise, it is concluded that foreign sales and asset size variables do not have moderating effect between changes in exchange rates and return on equity.

As a result, it is determined that changes in foreign exchange rates, foreign sales and asset size of the companies do not have any significant impacts on the return on assets and return on equity during the period between 1999-2019 in Turkey. Companies' successful use of financial derivatives and in-house hedging methods to minimize the exchange rate exposure ensure that they are insensitive to changes in exchange rates (Dewenter et al. 2005: 120-122). It can be said that companies effectively use internal and external hedging methods that help reduce the adverse impacts of the changes in foreign exchange rates. In the literature, Bartov and Bodnar (1994) indicated that firms were likely be affected by the changes in exchange rates with a lag, and similarly, Mutluay and Turaboğlu (2013) also indicated that the changes in exchange rates affected financial performance with a lag. The results of the study comply with these studies in the literature.

The study also finds that asset size and foreign sales do not have a moderating effect on return on equity and return on assets of foreign sales although asset size has a moderating effect on return on assets. Accordingly, as asset size which has a moderating effect increases if there is no change in profit, the return on assets ratio would decrease. Such an inverse moderating effect may occur between asset size and return on assets. Moreover, as the increase in exchange rates affect costs negatively, profit would decrease, and return on assets may be adversely affected.

The present study focuses on large-sized companies with publicly offered stock shares operating in public and manufacturing sectors in Turkey. Therefore, the indicators obtained from the published data determined the limit of the study. It should be taken into consideration that firms with smaller firm size, poorer access to external finance, and not listed on the stock exchange may also be more affected by exchange rate volatility. It is suggested that a study with broader data limitation, in which multivariate statistical estimation methods would be applied for different sectors, and by utilizing various independent variables, can be a source of motivation for future researchers. Consequently, performing similar studies on firms operating in countries other than Turkey would be useful for drawing general conclusions that may apply more broadly. 


\section{REFERENCES}

Adler, M. and Dumas, B. (1984). Exposure to currency risk: definition and measurement. Financial Management, 13(2), $41-50$.

Akalın, G. and Uzgören, E. (2016). Reel döviz kuru hareketlerinin firma performansına etkisi: Türk firmaları üzerine ampirik bir çalışma. Journal of The Faculty of Economics and Administrative Sciences, 6(1), 449- 469.

Akkuş, B. (2010). Finans yönetim: paraya hükmetmenin sırrı. 2. Baskı. İstanbul: Kumsaati Yayın Dağıtım Ltd. Şti.

Baggs, J., Beaulieu, E. and Fung, L. (2009). Firm survival. performance. and the exchange rate. Canadian Economics Association. 42 (2), $393-421$.

Bartov, E. and Bodnar, G. M. (1994). Firm valuation. earnings expectations. and the exchange-rate exposure effect. The Jornal of Finance. 49(5), 1755- 1785.

Bodnar, G. M. and Wong, M. H. F. (2003). Estimating exchange rate exposures: issues in model structure. Financial Management. $32(1)$, $35-67$.

Bolat, B. A. (2009). Firma performansını etkileyen faktörlerin yapısal eşitlik modeli ile incelenmesi. Yayımlanmamış doktora tezi. İstanbul Üniversitesi Sosyal Bilimler Enstitüsü, İstanbul.

Boyacıoğlu, M. A. and Çürük, D. (2016). Döviz kuru değişimlerinin hisse senedi getirisine etkisi: borsa istanbul 100 endeksi üzerine bir uygulama. Muhasebe ve Finansman Dergisi, 70, 143- 156.

BUSINESSHT. (2019, November 3). Business HT Bloomberg HT. Retrieved from https://businessht.bloomberght.com/ piyasalar/haber/1583151aktif-krlilik-nedir

Büker, S., Aşıkoğlu, R. and Sevil, G. (2014). Finansal yönetim. (8. Baskı). Ankara: Sözkesen Matbaacılık.

Dewenter, K. L., Higgins, R. C. and Simin, T. (2005). Can event study methods solve the currency exposure puzzle? Pasific-Basin Finance Journal. 13(2), 119- 144.

Dhasmana, A. (2013). Real effective exchange rate and manufacturing sector performance: evidence from indian firms. Indian Institute of Management Bangalore. Working Paper, 412.

Doğanay, M. (2016). Döviz kuru riski yönetimine sektörel bir yaklaşım. International Journal of Cultural and Social Studies. 2(1), $149-164$.

Doğukanlı, H. (2001). Uluslararası finans. Adana: Nobel Kitabevi.

Doidge, C., Griffin, J. and Williamson, R. (2006). Measuring the economic importance of exchange rate exposure. Journal of Empirical Finance. 13(4-5), 550- 576.

Dumitrescu, E-I. and Hurlin. C. (2012). Testing for granger non-casuality in heterogeneous panels. Economic Modelling. 29(4), 1450- 1460.

Düzakın, H. G. (2013). iş̧letme finansmanı. Ankara: Seçkin Yayıncılık.

Fung, L. and Liu, J-T. (2009). The impact of large real exchange rate movements on firm performance: a case study of taiwanese manufacturing firms. Japan and the World Economy. 21(1), 85- 96.

Göktaş, P., Pekmezci, A. and Bozkurt, K. (2019). Ekonometrik serilerde uzun dönem eşbütünleşme ve kısa dönem nedensellik. (2. Baskı). Ankara: Gazi Kitabevi.

Gürbüz, S. (2019). Aracı. düzenleyici ve durumsal etki analizleri. Ankara: Seçkin Yayıncılık.

Güriş, S. (2015). Stata ile panel veri modelleri. İstanbul: Der Yayınları.

Hanagaki, T. and Hori,M. (2015). The exchange rate and the performance of japanese firms: a preliminary analysis using firm-level panel data. Esri International Conference 2015: To Ensure Japan's Economic Growth. Economic and Social Research Institute. Cabinet Office-Japan, July 31st. 2015, 1- 28.

Jorion, P. (1990). The exchange rate exposure of U.S. multinationals. The Journal of Business. 63(3), $331-345$.

Karluk, R. (2003). Uluslararası ekonomi.( 7. Baskı). İstanbul: Beta.

Karluk, R. (2009). Uluslararası ekonomi: Teori-Politika. (9. Baskı). İstanbul: Beta.

Kelilume, I. (2016). Exchange rate volatılıty and firm performance in nıgerıa: a dynamıc panel regressıon approach. The Journal Of Developing Areas. 50(6), 161- 174

Kızıl. C. and Erdal, F. (2012). Türkiye'de imalat sanayindeki firmaların performansı ile reel döviz kuru arasındaki ilişki. 3rd International Conference on Economics Turkish Economic Association. ICE-TEA. İzmir. November 1-3. 2012, 3- 32.

Madura, J.(2012). International financial management. (11th Edition). South Western: Cengage Learning. 
Mutluay, A. H. and Turaboğlu, T. T. (2013). Döviz kuru değişimlerinin firma performansına etkileri: Türkiye örneği. BDDK Bankacılık ve Finansal Piyasalar, 7, 59- 78.

Müftüoğlu, T. M. (2010). İşletme iktisadı. (7. Baskı). Ankara: Turhan Kitabevi.

Sarıkovanlık, V., Koy. A., Akkaya. M., Yıldırım. H. H. and Kantar. L. (2019). Finans biliminde ekonometri uygulamaları. Ankara: Seçkin Yayıncılık.

Seyidoğlu, H. (2003). Uluslararası finans. (4. Baskı). İstanbul: Güzem Can Yayınları.

Tatoğlu, Y. F. (2012). Ileri panel veri analizi. İstanbul: Beta Yayıncllık.

Tomlin, B. and Fung, L. (2010). The effect of exchange rate movements on heterogeneous plants: a quantile regression analysis. Bank of Canada Working Paper, 25, 1- 30.

Yıldız, R. (1988). Bankacılıkta ve dış ticarette döviz pozisyonlarının kur riskine karşı korunması. Ankara: Türkiye İ̧̧ Bankası Kültür Yayınları.

Yücel, T. and Kurt, G. (2003). Foreign exchange rate sensitivity and stock price: estimating economic exposure of Turkish companies. European Trade and Study Group Fifth Annual Conference, Madrid. 11-13 September 2003, 1- 11.

Williams, H. T. (2018). An empirical investigation of the impact of exchange rate fluctuations on the performance of selected listed firms in nigeria. Journal of Business Management and Economic Research. 2(3), 1- 10. 